\title{
Prediction of Inundation Areas Due to Failure in Small Earthfill Dam Using Numerical Analysis
}

\author{
Daisuke SHODA*, Osamu KAWAMOTO, Hiroshi YOSHISAKO and \\ Keisuke INOUE
}

Facilities and Geotechnical Engineering Research Division, National Institute for Rural Engineering,

National Agriculture and Food Research Organization (NARO) (Tsukuba, Ibaraki 305-8609, Japan)

\begin{abstract}
This study aimed to verify the accuracy of inundation analysis by comparison with field-survey results for a small agricultural earthfill dam that failed due to heavy rain. In Japan, dam failures are caused by concentrated heavy rain or large earthquakes. Potential inundation areas are displayed on municipal "Hazard Maps" to reduce the risk of damage to downstream sites. However, the accuracy of inundation analysis for small earthfill dams has never been verified through comparison with field surveys. The following work was completed; i) the effect on the downstream gradient was verified by a simplified (one-dimensional unsteady flow) analysis for a case of dam failure; ii) the water depth and width of flow path in inundation areas were compared based on differences in peak outflow; and iii) the effect of the culvert structure blocked by flood debris downstream was also verified by comparing the result of analysis and the field survey. The following results were obtained: i) From the simplified analysis, the downstream water depth was sensitive to changes in outflow distribution from the dam breach section: ii) In the inundation analysis, using the peak outflow prediction equation proposed by Costa (1988), the water depth was deeper at the center of the flow path and the flow path was wider: iii) The water depth around the blocked culvert structure matched the field-survey results (the elevation data of the meshes around the culvert structure were raised to simulate the blocked structure).
\end{abstract}

Discipline: Agricultural engineering

Additional key words: analysis of inundation, dam for irrigation, heavy rain, outflow

\section{Introduction}

Heavy rain and large earthquakes are extremely damaging to irrigation facilities. Small earthfill dams used for irrigation in Japan are particularly prone to damage, since some of them were built over 400 years ago. The degree of embankment compaction is lower than that in modern design, and there is less control. Accordingly, disaster-prevention measures are essential to minimize the damage to humans and facilities in the case of dam failure. Information on predicted flood areas and evacuation routes is provided to the inhabitants near small earthfill dams in the form of municipal Hazard Maps, which are based on flood inundation analysis. Flood research is also conducted on riverbanks, landslide dams and earthfill dams. A manual on inundation analyses for river floods was issued by the Public Works Research Institute (Kuriki et al. 1997). A twodimensional unsteady model was used to verify the river flow during the flood discharge and the process of inunda- tion of protected lowlands caused by a typhoon in 2009 (Uno et al. 2010). A new one-dimensional model for the river bed variations and flood runoff have been proposed for landslide dams (Satofuka et al. 2007). This model is composed of a two-layer model for immature debris flow and a bank erosion model, applied to the landslide dam formed by the typhoon in 2005.

For small earthfill dams, the cost-benefit performance associated with floods was reported by Tani et al. (2009) and an inundation disaster prevention system was developed by Inoue et al. (2009), while Greg (2007) reported on embankment overtopping and failure analysis in the US and EU. In the UK, a study was conducted on the risks associated with reservoirs, and methodology for quantitative risk assessment was reported by Hughes et al. (2000).

It is important to survey the potential inundation areas of a dam impoundment due to failure (Fig. 1). In this study, i) the water depth results in a case of dam failure were verified using simplified analysis for six types of outflow from the dam breach section; ii) inundation areas were compared 


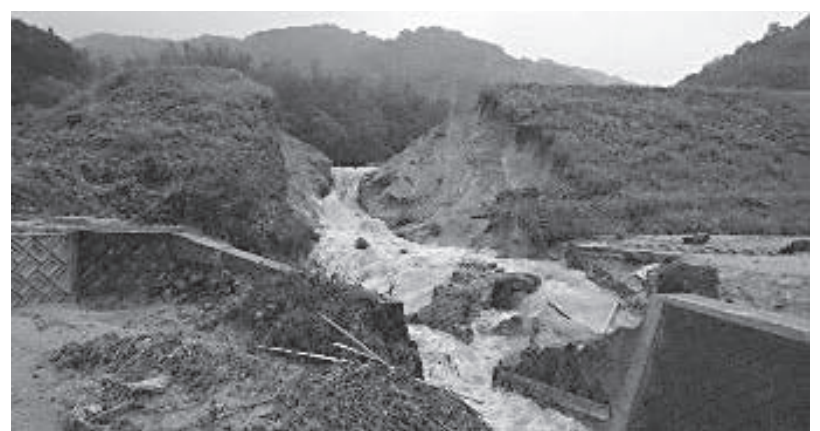

Fig. 1. Dam failure

based on the difference in peak outflow, and iii) the effect of culvert structure blocked by flood debris was verified through comparison with the field-survey results.

\section{Simplified analysis for outflow}

\section{Method of simplified analysis}

The scale of the dam and failure section used in this study are shown in Table 1. The downstream gradient, which was calculated from the dam embankment to the damaged house, is also shown. The average value represents the average of the top and bottom widths in the breached section.

The simplified analysis was formulated as a onedimensional unsteady flow equation. The governing equations were shallow water equations using an explicitly different method for the discretization. The grid cell size was $11 \mathrm{~m}$ and the roughness coefficient was 0.04 (Tani et al. 2009). The forest area is the value adapted by the Japan Society of Civil Engineers (1999). The time interval of analysis was $0.005 \mathrm{~s}$. The analytical region was $880 \mathrm{~m}$ the downstream from the dam embankment. The analytical width and gradient were $21.25 \mathrm{~m}$ and 0.14 , respectively, as shown in Table 1. The outflow hydrograph for an earthfill dam was shown by Greg (2007). The shape of this distribution is similar to normal distribution, but was not formulated. In this paper, the normal distribution was hypothesized as a hydrograph and was referred to as a water depth change in a riverbank failure by Yasuda et al. (2003). The hydrograph equations are as follows:

$$
Q_{(t)}=\left(Q_{\max }-Q_{\text {base }}\right) \cdot \exp \left\{-\frac{\left(t-t_{p}\right)^{2}}{2 \sigma^{2}}\right\}
$$

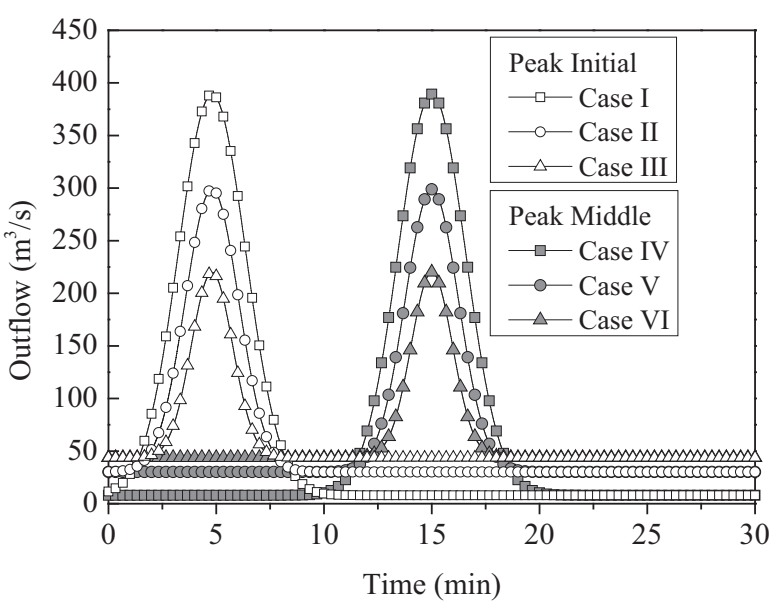

Fig. 2. Hydrograph at outflow point

$$
\begin{aligned}
& \sigma=0.659 T_{3 / 4} \\
& T_{3 / 4}=0.328 Q_{\text {max }}+15.167
\end{aligned}
$$

where $Q_{\max }$ is the peak outflow per second, $Q_{\text {base }}$ is the initial outflow per second, $t$ is time, $t_{\mathrm{p}}$ is peak time, and $T_{3 / 4}$ is time at three-quarters of the water level. The hydrograph at the outflow point is shown in Fig. 2. Total outflow time is 30 min, as determined from interviews. Time at peak outflow $\left(t_{\mathrm{p}}\right)$ refers to "initial" and "middle" cases during the total outflow time (30 $\mathrm{min})$ to compare water depth in the downstream area. Time at peak outflow for the initial case is 4.8 minutes and 15 minutes for the middle case.

The six outflow cases in this study are shown in Table 2. Total outflow is almost equivalent to the reservoir capacity.

\section{Results of the simplified analysis}

The water depth at a point $550 \mathrm{~m}$ from the outflow, as shown in Fig. 3, is the distance from the damaged house to the failed A-dam shown in Table 1. The water depth shape is equivalent to the outflow shape regardless of the gradient of the dam downstream site. This indicates that the downstream water depth is extremely sensitive to changes in outflow distribution.

\section{Method used to analyze inundation}

\begin{tabular}{|c|c|c|c|c|c|c|c|c|c|}
\hline \multirow[b]{2}{*}{$\begin{array}{l}\text { Dam } \\
\text { name }\end{array}$} & \multicolumn{4}{|c|}{ Dimensions of breach cross section } & \multirow[b]{2}{*}{$\begin{array}{c}\text { Reservoir } \\
\text { capacity } \\
V\left(\mathrm{~m}^{3}\right)\end{array}$} & \multirow[b]{2}{*}{$\begin{array}{l}\text { Height } \\
H(\mathrm{~m})\end{array}$} & \multirow[b]{2}{*}{$\begin{array}{l}\text { Length of } \\
\text { embankment } \\
\text { (m) }\end{array}$} & \multirow[b]{2}{*}{$\begin{array}{l}\text { Reservoir } \\
\text { area }\left(\mathrm{m}^{2}\right)\end{array}$} & \multirow[b]{2}{*}{$\begin{array}{l}\text { Gradient of } \\
\text { downstream }\end{array}$} \\
\hline & $\begin{array}{l}\text { Top } \\
\text { width } \\
(\mathrm{m})\end{array}$ & $\begin{array}{l}\text { Bottom } \\
\text { width } \\
(\mathrm{m})\end{array}$ & $\begin{array}{l}\text { Average } \\
\text { (m) }\end{array}$ & $\begin{array}{l}\text { Height } \\
H w(\mathrm{~m})\end{array}$ & & & & & \\
\hline A-dam & 38.5 & 4 & 21.25 & 10.34 & 103,600 & 14.8 & 76.0 & 17,000 & 0.140 \\
\hline
\end{tabular}

The method used to analyze the inundation was a two-

Table 1. Dimensions of the failed dam 
Table 2. Hydrograph parameters

\begin{tabular}{|c|c|c|c|c|}
\hline & $Q_{\max }\left(\mathrm{m}^{3} / \mathrm{s}\right)$ & $Q_{\text {base }}\left(\mathrm{m}^{3} / \mathrm{s}\right)$ & $t_{\mathrm{p}}(\mathrm{h})$ & Calculation of $Q_{\max }$ \\
\hline Case I & 388.9 & 7.6 & 0.08 & $325(H V)^{0.42}($ Costa $(1988)$ or see Table 1$)$ \\
\hline Case II & 298.4 & 29.7 & 0.08 & $0.607 V^{0.295} H_{1}{ }^{24}$ (Froehlich $(1995)$ or see Table 1$)$ \\
\hline Case III & 219.7 & 43.4 & 0.08 & Cross section area of dam break (see Table 1) \\
\hline Case IV & 388.9 & 7.6 & 0.25 & $325(H V)^{0.42}($ Costa $(1988)$ or see Table 1$)$ \\
\hline Case V & 298.4 & 29.7 & 0.25 & $0.607 V^{0.295} H^{1.24}$ (Froehlich (1995) or see Table 1) \\
\hline Case VI & 219.7 & 43.4 & 0.25 & Cross section area of dam break (see Table1) \\
\hline
\end{tabular}

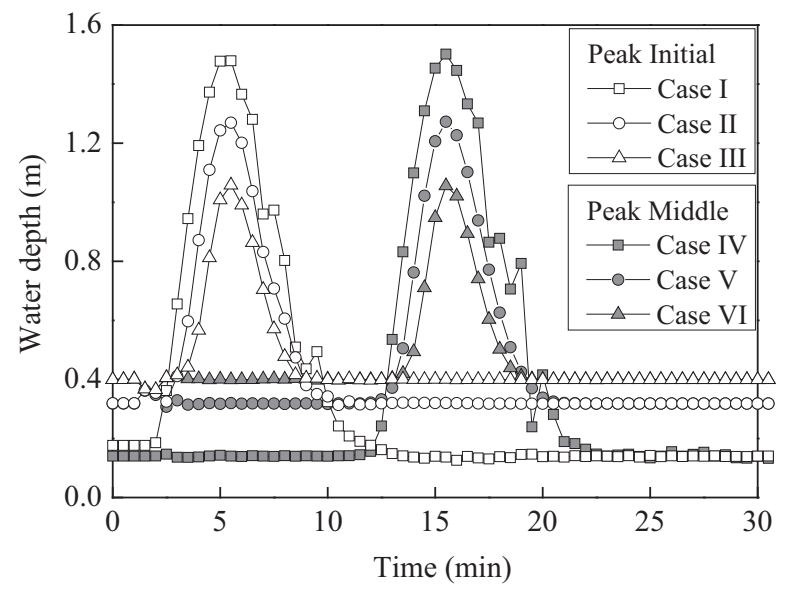

Fig. 3. Variations in water depth at point of damaged house

dimensional unsteady flow equation. Motion and continuity equations are as follows:

$$
\begin{aligned}
& \frac{\partial h}{\partial t}+\frac{\partial M}{\partial x}+\frac{\partial N}{\partial y}=0 \\
& \frac{\partial M}{\partial t}+\frac{\partial(v M)}{\partial x}+\frac{\partial(u M)}{\partial y}=-g h \frac{\partial h}{\partial x}-\frac{\tau_{\mathrm{xb}}}{\rho}, \\
& \tau_{\mathrm{xb}}=\frac{\rho g n^{2} v \sqrt{u^{2}+v^{2}}}{h^{1 / 3}}
\end{aligned}
$$

$$
\begin{array}{r}
\frac{\partial N}{\partial t}+\frac{\partial(v N)}{\partial x}+\frac{\partial(u N)}{\partial y}=-g h \frac{\partial h}{\partial y}-\frac{\tau_{\mathrm{yb}}}{\rho}, \\
\tau_{\mathrm{yb}}=\frac{\rho g n^{2} u \sqrt{u^{2}+v^{2}}}{h^{1 / 3}}
\end{array}
$$

where $x$ is east-west direction ( $x$-direction), $y$ is north-south direction ( $y$-direction), $t$ is time, $g$ is acceleration due to gravity, $h$ is water depth, $\rho$ is water density, $v$ is velocity in the $x$-direction, $u$ is velocity in the $y$-direction, $M$ is flux in the $x$-direction, $N$ is flux in the $y$-direction, $\tau_{\mathrm{xb}}$ is shear stress at the bottom surface in the $x$-direction, and $\tau_{\mathrm{yb}}$ is shear stress at the bottom surface in the $y$-direction. The analysis was conducted on the dam shown in Table 1, with elevation data obtained from the Fundamental Geospatial Data of the Geospatial Information Authority of Japan (GSI). The mesh size was $5 \times 5 \mathrm{~m}$. The analytical area was $550 \mathrm{~m}$ in the $x$ direction and $595 \mathrm{~m}$ in the $y$-direction, and the mesh numbers were 110 and 119 , respectively. The roughness coefficient was 0.04 and the time interval of analysis was $0.03 \mathrm{~s}$. The outflow for Cases IV and VI in Table 2 was used to compare the downstream inundation conditions resulting from large and small peak outflow. The width of outflow point was $20 \mathrm{~m}$, which was the value adopted for multiple 5-m meshes and close to the average breach width $(21.25 \mathrm{~m})$ as shown in Table 1. As shown in Fig. 4, the cul-

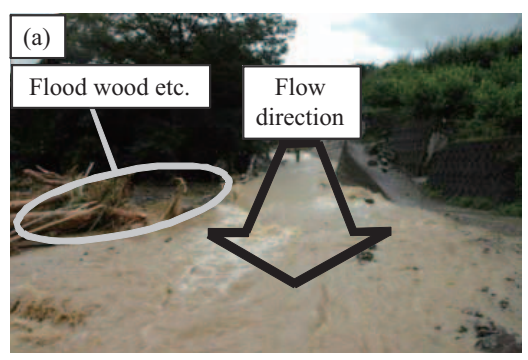

(a) Blocked culvert structure at flood

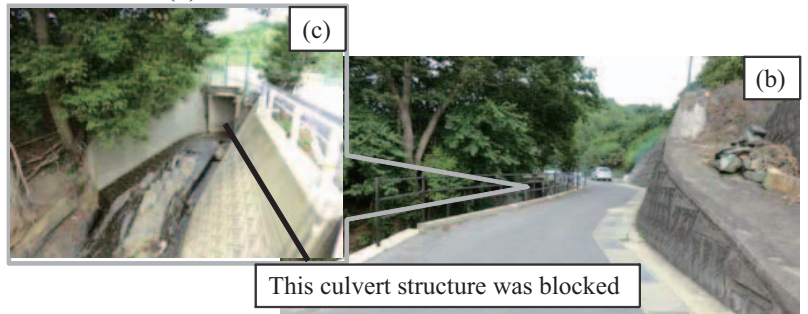

(b) Photo at same location as (a) (c) Culvert structure after removing the flood debris

Fig. 4. Culvert structure located downstream of earthfill dam 


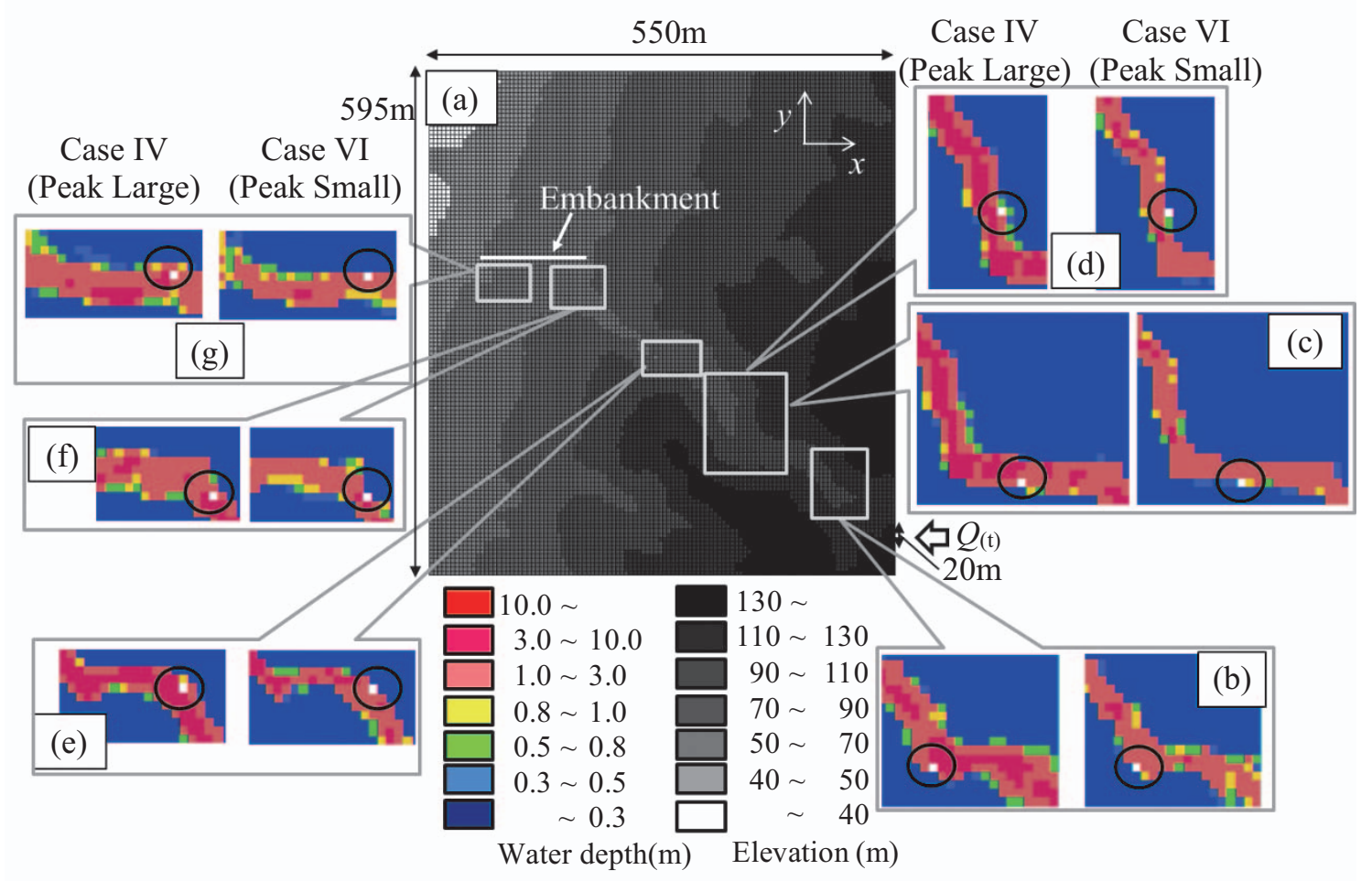

Fig. 5. Contour map of elevation in analytical region and maximum water depth (Left side is Case IV, right side is Case VI (outflow pattern, see Table 2))

vert structure downstream appears to be blocked by flood debris (wood or mud and sand). The results using normal elevation were invalid because the blocked culvert structure was not simulated. The proposed method for this simulation is described later.

\section{Results of inundation analysis}

\section{Effect of outflow against inundation area}

Contour maps of the elevation and maximum water depth at each section are shown in Figs. 5 (a) and (b)-(g). The dam failure point is shown at the bottom right of Fig. 5 (a). The white mesh circled with a black line in Figs. 5 (b)(g) shows the same position for Cases VI and IV. At the center of the flow path, the water depth in Case IV is deeper than that in Case VI in Fig. 5 (b)-(g). The width of the flow path shown in Case IV is also slightly wider than that shown in Case VI. The embankment shown in Figs. 5 (f) and (g) exists in $x$-direction, and the outflow was not over the embankment, which matches the field-survey results.

\section{Effect of blocked culvert}

It is proposed that the elevation of the culvert structure rises from the original elevation because the elevation was raised to simulate the flow path of the culvert structure blocked by flood debris (wood or mud and sand). Using the outflow pattern of Case IV (Costa 1988), the elevation of the culvert structure rises $3 \mathrm{~m}$ from the original elevation. The height of the culvert structure was 3 m. Fig. 6 shows a contour map of the elevation in the analytical region and a contour map around the culvert structure with the change in elevation. The four meshes with elevation change are indicated in Fig. 6 (b).

Fig. 7 shows the maximum water depth around the culvert structure with the change in elevation. The four meshes with red frames in Fig. 7 (b) indicate the locations of elevation change. Comparing Figs. 7 (a) and (b), the latter shows a water depth of about $3 \mathrm{~m}$ at the downstream site (circled in black) of the blocked culvert structure. In Fig. 7 (a), the depth is lower than $3 \mathrm{~m}$ in the section circled in black. Evidence of inundation area for the field survey was confirmed at a water depth of about $3 \mathrm{~m}$ around the culvert structure. The analytical results based on changes in elevation matched the field-survey results.

\section{Summary}

This study verified the accuracy of inundation analysis for an actual small agricultural earthfill dam that failed due to heavy rain. Total outflow time was determined from interviews. The normal distribution was hypothesized as a hydrograph. i) The results of simplified analysis using a one-dimensional unsteady flow equation revealed that the downstream water depth was sensitive to the outflow distri- 


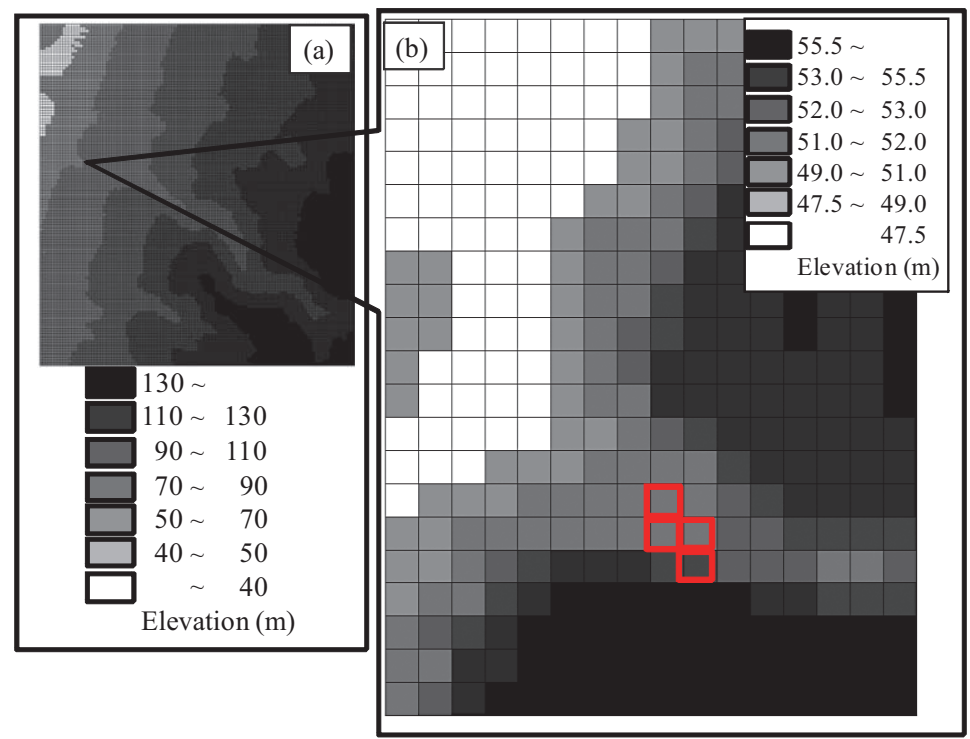

Fig. 6. (a) Contour map of elevation in analytical region (b) Contour map of elevation around culvert structure with change in elevation

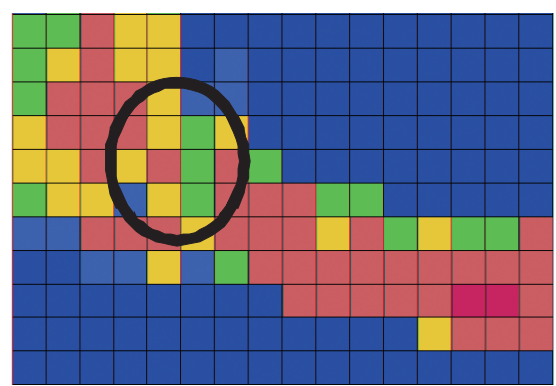

(a) Normal case

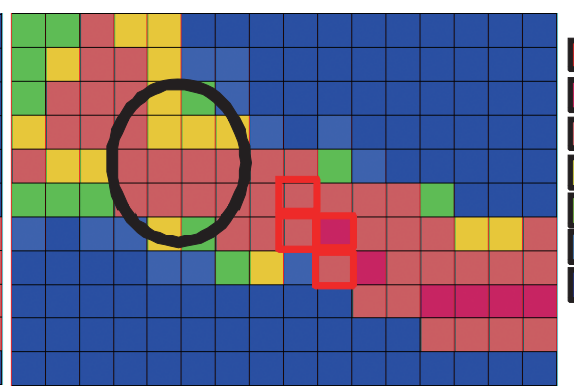

(b) Case of blocked culvert

Fig. 7. Maximum water depth around culvert structure with change in elevation

bution from the dam breach section. ii) The analytical results using the peak outflow equation proposed by Costa (1988) revealed that the water depth was deeper at the center of the flow path and the flow path was wider. iii) In the inundation analysis, changes in elevation were used to confirm the effect of the blocked culvert and the analytical results matched the field-survey results.

\section{Conclusions}

i) Based on the results of simplified analysis, the water depth shape is equivalent to the outflow shape. The downstream water depth was sensitive to changes in outflow distribution from the dam breach section regardless of the gradient of the downstream dam site.

ii) Based on analytical results, using the peak outflow equation proposed by Costa (1988), the water depth was deeper at the center of the flow path and the flow path was wider. The results of this analysis around the embankment are valid because the water also did not reach the back side of the embankment in the field survey.

iii) The culvert structure was blocked with flood debris (wood or mud and sand) downstream. The elevation of the culvert structure was raised $3 \mathrm{~m}$ from the original elevation to simulate the blocked culvert. The water depth around the blocked culvert structure matched the field-survey results.

\section{Acknowledgments}

We sincerely thank Wakayama prefecture and Kinokawa city for kindly providing some of the data used in this study.

\section{References}

Costa, J. (1988) Floods from Dam Failure. Flood Geomorphology, 436-439.

Froehlich, D. (1995) Peak Outflow from Breached Embankment Dam. J. Water Resources Planning and Management, 121, 90-97.

Greg, H. (2007) The National Dam Safety Program. Federal 
Emergency Management Agency (FEMA), USA.

Hughes, A. et al. (2000) Risk management for UK reservoirs, Construction Industry Research \& Information Association (CIRIA).

Inoue, K. et al. (2009) Construction of a disaster reduction system by flood analysis. Nougyonousonkougakkaishi (Water Land and Env. Eng.), 77(11), 7-10 [In Japanese].

Japan Society of Civil Engineers (1999) Hydraulics Formulae JSCE1999. 131 [In Japanese].

Kuriki, M. et al. (1997) Manual of inundation analysis. Dobokukenkyujo Shiryou (Technical Note of PWRI) [In Japanese].

Satofuka, Y. et al. (2007) Prediction of floods caused by landslide dam collapse. Suikougaku Ronbunshuu (51st Conf. on
Hydraulic Eng.), 901-906 [In Japanese with English abstract].

Tani, S. et al. (2009) Analysis of inundation caused by failure of small earth dams and the way of evaluation of the damage in the downstream sites. Nousonkougaku Kenkyujyo Gihou (Tech. Rep. Natl. Inst. Rural Eng. Japan), 210, 137-144 [In Japanese].

Uno, K. et al. (2010) Preliminary report of heavy rainfall disaster caused by typhoon No. 0909. Suikougaku Ronbunshuu (54th Conf. on Hydraulic Eng.), 865-870 [In Japanese].

Yasuda, H. et al. (2003) Development of rapid numerical inundation model for the levee protection activity, Dobokugakkai Ronbunshuu (J. of JSCE), No. 740/II-64, 1-17 [In Japanese with English abstract]. 